\title{
Teaching Grammatical Aspects of the Turkish Language as Means of Students' Communicative Competences Formation at the Initial Stage of Training
}

\author{
Liliya Sh. Shafigullina ${ }^{1}$ \\ ${ }^{1}$ Kazan (Volga Region) Federal University, Kazan, Russia \\ Correspondence: Liliya Sh. Shafigullina, Kazan (Volga Region) Federal University, 420008, Kazan, \\ Kremlyovskaya Street 18, Russia. E-mail: Liliyashamilovna@mail.ru
}

Received: June 2, 2015 Accepted: June 15, 2015 Online Published: June 29, 2015

doi:10.5539/jsd.v8n5p34 URL: http://dx.doi.org/10.5539/jsd.v8n5p34

\begin{abstract}
The relevance of this article is caused by the insufficient development of the research on learning the grammatical peculiarities of the Turkish language, which enhances the effectiveness of learning Turkish speech, which would be focused on the development of procedural communicative speech qualities of the student's personality. In this context, this article serves as the attempt to solve the problem of improving the effectiveness of teaching grammatical aspects of the Turkish language. The leading approach to the study of the problems stated in the article was the communicative approach based on the theory of stepwise formation of mental actions. The article deals with the psychological and pedagogical foundations and linguodidactic mastering of the foreign language (Turkish) speech activity of students at the initial stage of education. Overview of typical mistakes made by students in the study of particular grammatical phenomena of the Turkish language is provided in the article. Among the grammatical peculiarities of the Turkish language presented in this study we see the possessive case of the nouns, rules of agreement of the Turkish adjectives and numerals with nouns, as well as the order of words in a simple sentence. Materials of the article can be useful for teaching the Turkish language in gymnasiums, lyceums and can also serve as the basis for training the Turkish language specialists in higher education establishments.
\end{abstract}

Keywords: scientific, word order, linguistic bases, agglutinative languages

\section{Introduction}

In the regions of Russia, along with the development of the state languages is steadily increasing the role of foreign, especially oriental languages, which is associated with need for communication, exchange of experiences between the peoples in the new environment. The restructuring of social life in the last decade has led to the expansion of economic, political and cultural ties between Russia and other countries that require deep knowledge of sustainable language skills needed for full language communication in different situations, as " we can call the man a bilingual when he is competent enough in at least two languages and is able to use them in all circumstances with similar efficacy" (Xiguang \& McKee, 1990). It means that the language of the students should be in keeping with the language being studied. The importance and relevance of the study of teaching conditions and technologies of language learning is also determined by the children's natural interest in practical knowledge of two or more languages (Shafigullina, 2006). Therefore, the development of a foreign language (Turkish) didactic system aimed at students' speech activity is currently one of the most urgent problems of teaching and culture-oriented linguistics (Shafigullina, 2006).

Consequently, purposeful formation of bilingualism (multilingualism) in the education system should contribute to the practical mastery of foreign languages, including Turkish, which involves the development of verbal communication skills in training activities, household, official business and socio-cultural spheres (Szczerba, 1974).

In this regard, teaching of the Turkish language at the university acquires special importance. Besides the development of the Turkish language learning content and system comes as a top-priority task (Shafigullina, 2006).

The relevance of this article comes from the insufficient development of the research on learning the 
grammatical peculiarities of the Turkish language, which determines the effectiveness of learning the Turkish speech, focused on the development of procedural communicative speech qualities of the student's personality.

The purpose of the study is identification and substantiation of the foreign language teaching conditions for the development of speech activity of students at the initial stage.

The scientific novelty of the research lies in the fact that the work presents the attempt to solve the problem of increasing the efficiency of teaching grammatical aspects of the Turkish language.

\section{Methodological Framework}

The methodological basis of the study lies on the psychological, pedagogical and linguodidactic works oriented to the process of the formation of students' oral speech activity from the perspective of developing the culture of verbal communication, the trainees' desire for self-development and self-education; on the systematic and student-active approach to the process of oral speech formation; on the theory of developmental education, the growing cognitive independence and zeal, stepwise formation of mental activity.

Of particular importance for our study were the works of scholars in the field of psychology (Vygotsky, 1982; Zhinkin, 1955 et al.); methods: a) foreign languages (Vereshchagin, 1969; Passow, 1986); b) Turkish (Dmitriev, 1960; Rakhimov, 2002); c) the Russian language as native and non-native (Asadullin, 1991; Dmitriev, 1951); d) the Tatar language (Kharisov, 2000; Kharisov and Kharisova, 2001).

Grammatical system in the process of language learning is the guiding force that led to the practical mastery of the language. This proposition has gained convincing evidence in studies of L.V. Shcherba: "... saying language we mean perhaps first and foremost its grammar" (Szczerba, 1974). These words are directly related to the Turkish language.

The importance of various grammatical phenomena in the process of selection of the content and training systems to the Turkish language is determined by the following factors:

a) the specificity of the very system of the Turkish language as compared to the native language of students;

b) the degree of similarity and difference of the Turkish language with the students' native language;

c) the methodological feasibility of introducing certain linguistic units in the process of learning the Turkish language at the initial stage.

The agglutinative languages are characterized by the gradual and mechanical accession of affixes to the root. Besides all important parts of words can serve as morphemes. Therefore, we can distinguish root morphemes, affixal preformative and affixal grammatically (shaping) valued morphemes. Affixes, in turn, are divided into suffixes (affixes standing after the root) and prefixes (affixes facing the root). Affixes in Turkish are introduced by morphemes standing at the end of words and expressing the ratio of the word to other words in sentences (Kuznetsov, 2005).

\section{Results}

A distinctive feature of the Turkish language nouns is a possessive case. It is when the special affixes express the affiliation of the subject to a person: benim kalem-im - my pen (pen), senin kalem-in - your pen, onun kalem-i his (her) pen (with pen), bizim kalem-imiz - our pen, sizin kalem-iniz - your pen), onlarin kalem-i - their pen (with pen).

In Turkish possessiveness can be expressed:

a) in a synthetic way - with the help of possessive affixes: kalem-im;

b) the analytical method - a combination of the personal pronoun in the possessive case with a noun: benim kalem;

c) the analytic-synthetic method - a combination of the personal pronoun in the possessive case with a noun having a possessive affix of a certain type: benim kalem-im (Kuznetsov, 2005).

To practice the skills of using words with possessive affixes we can offer the activity with the following wording: 1) Fill in the possessive affixes: benim çant ......., senin okul ......., onun arkadaş ......, bizim teyze ....... 2) Translate the following phrases: arkadaşımın evi, ablamın elbisesi, annemin teyzesi, ablamın kedisi, komşumun cocuğu.

The Turkish language learning difficulty can also be caused by the adjectives. In Turkish adjectives do not vary by gender, number and case. They are bound to the noun just by the contiguity method: interesan kitap - an interesting book, interesan dergi - an interesting magazine, büyük evler - big houses, kü̧̈ük çocuklar - small 
children, tembel ögrenci - a lazy student. As you know, in Russian adjectives agree with the nouns to which they refer in gender, number and case (bol'shoi gorod - big city, bol'shaya sumka - a big bag, bol'shoe okno - a large window). Therefore, it is difficult for students to comprehend the specific feature of adjectives in a foreign language; they cannot understand that to the nouns sokak - a street, masa - a table, sira - a desk we can pick the same adjective genis - wide.

To consolidate the skills of using adjectives you can use the following tasks: 1) Make up a phrase using the following adjectives and nouns: güzel - beautiful, geniş - wide, küçük - small, klz - a girl, masa - a table, ev - a house. 2) Describe your friend using the following adjectives: güzel - beautiful, büyük - large, uzun - high, tembel - lazy, mavi - blue, sarı - yellow, siyah - Black, küçük - small, çalışkan - hardworking. 3) Translate the phrases given from Russian into the Turkish language: bol'shoi dom - a big house, dlinnaya rech' - a long speech, malen'kaya devochka - a little girl, zheltoe plat'e - a yellow dress, derevyannaya dver' - a wooden door, nizkii potolok - a low ceiling, shumnyi klass - a noisy class, yarkaya zvezda - a bright star.

The numerals in the Turkish language also possess some specific characteristics: they are usually used with the nouns by contiguity, and nouns typically have a singular form (beş ögrenci - five students). In the Russian language numerals have their own grammatical features: agreement with nouns is expressed with case forms of the singular and plural nouns (dva prepodavatelya - two teachers, desyat' uchebnikov - ten textbooks). Therefore, it is typical for students to make mistakes matching numerals with nouns. By analogy with the Russian language they usually use plural affixed nouns with numerals. For example, the phrase pyat' uchenikov - five students is translated as beş ögrenciler instead of beş öğrenci.

To exercise practical skills on "Numerals" we can offer the following tasks: 1) Answer the questions: Sinıfta kaç tane talebe var? - How many students are here in the class?; Bu ailede kaç tane cocuk var? - How many children are there in this family?; Senin kaç tane arkadaşın var? - How many friends do you have? 2) Define the word that is not a numeral: a) milyon - million; b) kırk - forty; a) bir - a unit; g) bir buçuk - a half; d) bin - thousand. 3) Translate the following phrases: dört ögrenci, beş defter, yirmi beş cocuk, altmış iki kedi, sekiz elma, on iki kalem.

It is also necessary to consider the fact that many Russian verbs with the same prefix may correspond to one verb of the Turkish language. For example, such verbs as prinosit' - to bring, privodit' - to bring, privozit' - to deliver has only one equivalent verb in the Turkish language - getirmek. Sometimes vice versa, to transmit the Russian prefixal verb to the Turkish language depending on the context we can use one, two and even three Turkish verbs. For example, in the Russian phrase "kachat' golovoi - shaking his head", "kachat' nasosom - swing with a pump", "parokhod kachaet - the ship shakes" there is only one verb "kachat". "In the process of translation to the Turkish language three separate verbs should be used: «başını sallamak», «pompa ile çekmek», «vapur yalpalaniyor». Therefore, in teaching Turkish we should take into consideration the fact that many Russian verbs are polysemous, as well as not to forget that there are a large number of collocations with a particular verb in the Turkish language.

The problem of a verbal aspect is among the most controversial issues still having no final decision. Verbs, combined with a variety of auxiliary verbs, could be called aspectual classes, but not species. These species have a value, but do not form an aspect itself. Teaching the Turkish language we are to be aware that some prefixal verbs of the Russian language can be transmitted into Turkish with the help of participial forms of the main verb in conjunction with a conjugate auxiliary verb. As an auxiliary verb we can use the following verbs: girmek, çıkmak and others. For example, verbs with prefixes which have a spatial meaning and refer to the various courses of action are transmitted by a combination of the main verb participle form and an auxiliary verb: sletet' - uçarak inmek (flying, go down), vbezhat' - koşarak girmek (running, enter), vybezhat' - koşarak çıkmak (running, exit) and others (Kuznetsov, 2005).

In the process of translation from Russian into Turkish we can face the difficulties associated with the fact that some Russian prefixal verbs are transferred to the Turkish language by means of adverbs or any other parts of speech in combination with an auxiliary verb, for example, to come - yanına gelmek, ahead - ónüne geçmek, fulfill - yerine getirmek, provide - göz önüne almak.

Further we will investigate the process of comparative description of the syntactic structures of the languages considered, as it plays a significant role in the initial stage of learning Turkish as a foreign language. The same time we shouldn't forget that the word order of the sentences in Turkish and Russian is determined by the following factors: the construction of sentences, the form of expression of the main parts of a sentence, the place of minor parts of a sentence. It should be recalled that the word order in a sentence depends on the subject and predicate of it. They serve as a connecting point for all other parts. In Russian, the word order is more free than 
in Turkey, as a result students often make up such type of sentences like Ben gidiyorum okula instead of Ben okula gidiyorum (I go to school); Benim babam çalışlyor fabrikada instead Benim babam fabrikada çallşsyor (My dad works in a factory).

To explain the essence of the typical errors in the students' speech associated with the word order in Turkish sentences, firstly we should consider the location of the main parts of the sentence which are the subject and the predicate in the Turkish and Russian languages. In both languages the subject expressed by a noun, pronoun, or substantivized part of speech is usually placed before the predicate expressed by the verbs of the indicative mood. For example: Talebe okuyor - Student reads. Ben okuyorum - I read. Predicate in the Turkish language is in the last position where all the secondary parts belonging to it placed before the predicate itself. For example: Aysse okula gidiyor. - Aisha goes to school.

The predicate of the Russian language may precede the subject. Typically, such sentences are introduced by the minor parts belonging to the predicate. For example: The vacation begins today. If the predicate expresses the process, action, it is also located in the beginning of a sentence: The Volga River runs.

About the minor parts of the Turkish and Russian sentences we can say the following:

a) in the Turkish language the attribute usually precedes the modified element: Bu kimin çantast? - Whose bag is this? Bu benim çantam. - This is my bag.

In the Russian language the agreeing attribute usually precedes and non-agreeing attribute comes after the modified element: Duet sil'nyi veter. - Strong wind is blowing. Dom iz kirpicha. - House is made of bricks;

b) in the Turkish language the object usually comes before the predicate, and in Russian follows it: Ahmet kitap okuyor. - Akhmet chitaet knigu. - Ahmet is reading a book.

c) the adverbial modifiers of time and place in both languages usually take place in the beginning of a sentence: Yazın biz köyde tatil yaptık. - Letom my otdykhali $v$ derevne. - In summer we had a rest in the countryside. Sokakta güzel arabalar geçiyor. - Na ulitse proezzhayut krasivye mashiny. - Beautiful cars are passing in the street;

g) the part of a sentence, containing some new information in the Turkish language usually comes before the predicate and is logically stressed. For example: Timur eve gidiyor. - Timur is going home. In Russian the part of the sentence, having logical stress, usually takes the last position: Deti igrayut na ulitse. - Children are playing in the street.

To practice the skills of constructing syntactic structures the following tasks can be offered: 1) Make up sentences, putting the words in the right order: a) Ayşe, geldi, sabah, okula; b) Fabrikada, çalışıyor, annem. a) Gitti, Ayhan, sinemaya; g) Ben, çıktım, erken, sinıftan. 2) Underline the adverbial modifiers of place in the following sentences: Evde güzel müzik çalıyor. - Here comes wonderful music from the house. Kışın biz köyde tatil yaptık. - In winter we had a rest in the countryside. Ben sinemada film seyrettim. - In the cinema I watched a movie. Cocuk sokakta futbol oynuyor. - The child is playing football in the street. 3) Make up simple sentences.

\section{Discussions}

It is generally accepted that the success of foreign language teaching process mostly depends on taking into account the features of learners' native language. It is known that a foreign language is usually learnt within the categories of the native language. And now the principle of taking into consideration the native language is not debatable, it is recognized by virtually all Methodists and received approval in the works of V.A. Bogoroditskaya (1935), L.3.Shakirova (1999) and many others. The main point of the interference is that "there in the mind of a speaker appears an image of the so-called third system in which the differentiating features of the Russian and native languages are mixed, it means that students establish some false correspondence between the units of the native language and the target one" (Shakirova, 1999). Transposition is the opposite mechanism, which can be described as a "positive impact" of the native language on the system of a foreign language, that is, the transfer of the identical features of the native language into the target language (Shakirova, 1999).

Therefore, the teacher should be sensitive to the period when students should be isolated from the lexical and grammatical influence of the native language in order to avoid interference, and when, on the contrary, should firmly fix in their minds the language associations using the positive influence of the native language which is a transposition (Shakirova, 1999).

In this regard, for example, comparative study of grammatical categories of Russian and Turkish belonging, as you know, to different typological groups will help to identify a good deal of discrepancies and mutually contrasting forms in each of them, which create great potential for using interference. 


\section{Conclusion}

Thus, teaching the grammatical aspects of the Turkish language at the initial stage of training at the level of morphology, particular attention should be paid to categories of possession, adjectives and numerals which have no morphological parameters, and at the level of syntax - the order of words in a sentence, the forms of expression of the sentence ought to be pointed out. And, of course, the effectiveness of teaching grammatical aspects is based on the results of the comparative analysis of phonetic, lexical, grammatical (syntactic and morphological) patterns of the languages in contact, based on the most common mistakes in students' speech.

Comparative-typological characteristics of the Turkish and Russian languages reveal the specific features of these languages and their influence on the process of learning the Turkish language. These data make it possible to predict the effects of interference and the use of transposition of the Russian language at all levels and to determine the most efficient ways of learning the Turkish language on this basis, including the ways of accent overcoming in the speech of students, where as the main source comes the interference. Determining the degree of interference of the Turkish and Russian languages in the formation of frequent speech errors helps to overcome the speech difficulties, and it is very important to choose the optimal strategy of learning the Turkish language.

\section{Acknowledgments}

The work is performed according to the Russian Government Program of Competitive Growth of Kazan Federal University

\section{References}

Asadullin, A. Sh. (1991). Osnovy metodiki russkogo yazyka v tatarskoi nachal'noi shkole [Basic methods of the Russian language in the Tatar primary school]. Kazan: Tatarskoe knizhnoe izdatel'stvo.

Bogoroditskii, V. A. (1935). Obshchii kurs russkoi grammatiki [The general course of Russian grammar]. Moscow-Leningrad.

Dmitriev, N. K. (1951). Narechiya mesta v turetskom yazyke. Sbornik "Pamyati akademika L.V.Shcherby" [Adverbs of place in the Turkish language. The collection "Memory of Academician L.V.Scherby."]. Leningrad.

Dmitriev, N. K. (1960). Turetskii yazyk [The Turkish language] (pp. 26-35). Moscow.

Kharisov, F. F. (2000). Nauchnye osnovy nachal'nogo obucheniya tatarskomu yazyku kak nerodnomu [Scientific basis of initial training as a foreign language Tatar]. Kazan.

Kharisov, F. F., \& Kharisova, Ch. M. (2001). Sovremennye tekhnologii obucheniya tatarskomu yazyku v russkoi shkole [Modern technologies of learning the Tatar language in a Russian school]. Kazan.

Kuznetsov, P. I. (2005). Uchebnik turetskogo yazyka. Chast' 2. Zavershayushchii kurs [Textbook of the Turkish language. 2. The final part of the course]. Moscow.

Passov, E. I. (1986). Kontrol' kak metodicheskii fenomen: genezis, sushchnost', funktsii (pri kommunikativnom metode obucheniya). Kontrol' v obuchenii inostrannym yazykam [Control as a methodical phenomenon: the genesis, nature, functions (with communicative teaching methods). Control of foreign language teaching] (pp. 13-19). Moscow.

Polivanov, E. D. (1991). Izbrannye raboty. Trudy po vostochnomu i obshchemu yazykoznaniyu [Selected works. Proceedings of the Eastern and general linguistics]. Moscow.

Rakhimova, A. R. (2002). Türk Dilbilgisi. Threk grammatikasy. Kazan.

Shafigullina, L. Sh. (2006). Didakticheskie usloviya razvitiya inoyazychnoi rechevoi deyatel'nosti studentov pedagogicheskogo vuza na nachal'nom etape (Doctoral dissertation) [Didactic conditions of development of foreign language speech activity of students of pedagogical high school at an early stage (Doctoral dissertation)]. Kazan.

Shakirova, L. Z. (1999). Osnovy metodiki prepodavaniya russkogo yazyka v tatarskoi shkole [Basic methods of teaching the Russian language in the Tatar school]. Kazan.

Shcherba, L. V. (1974). Yazykovaya sistema i rechevaya deyatel'nost' [Language system and speech activity]. Leningrad.

Siguan, M., \& Makki, Ch. F. (1990). Obrazovanie i dvuyazychie [Education and bilingualism]. Moscow.

Sovetkin, F. F. (1962). O novykh nauchno-metodicheskikh trebovaniyakh $k$ uchebnikam russkogo yazyka dlya 
natsional'nykh shkol (pp. 87-105). Rodnoi i russkii yazyk v natsional'noi shkole. [About the new scientific and methodological requirements of the Russian language textbooks for national schools (pp. 87-105). Native and Russian language in the National School]. Moscow.

Vereshchagin, E. M. (1969). Psikhologicheskaya i metodicheskaya kharakteristika dvuyazychiya (bilingvizma) [Psychological and methodological characteristics of bilingualism]. Moscow.

Vygotskii, L. S. (1982). Myshlenie i rech'. Sobranie sochinenii. Tom 2 [Thinking and speech. Works. Volume 2]. Moscow.

Zhinkin, N. I (1955). Vopros i voprositel'noe predlozhenie. Voprosy yazykoznaniya [Question and interrogative sentence. Problems of Linguistics.]. Moscow, 3, 30.

\section{Copyrights}

Copyright for this article is retained by the author(s), with first publication rights granted to the journal.

This is an open-access article distributed under the terms and conditions of the Creative Commons Attribution license (http://creativecommons.org/licenses/by/3.0/). 